\title{
The Decline Of The Middle Class In Jordan
}

\author{
https://doi.org/10.21272/sec.5(1).28-34.2021.
}

Prof. Dr. Jameel Aljaloudi, ORCID: https://orcid.org/0000-0002-2924-4119

Department of Planning and Project Management, College of Business, Al-Balqa Applied University, Jordan

\begin{abstract}
Declining economic growth in Jordan, rising unemployment and the abolition of state support for certain segments of the population have led to a deterioration in the welfare of the middle class in Jordanian society. The importance of the middle class for the country is due to the fact that they act as a driving force in creating a market economy, as well as implement creative and intellectual work. The article considers the essential importance of the middle class and its role in building a democratic and legal state, as well as in ensuring a stable pace of economic development. The purpose of this article is to analyze the level of decline in the middle class in Jordanian society during 2010-2017. The following indicators were used to conduct this study: average annual income, double the national poverty line and the share of the population that receive an average of $60 \%$ of income. The source of statistical information was the data of the World Bank and the General Statistics Department of Jordan. The author of the article proposes to calculate a generalized indicator for the characteristics of the middle class in society the average annual household income index. The study showed that during 2010-2017 there was a significant reduction in the size of the middle class in Jordan. The author suggests that such negative dynamics will persist in the coming years, especially given the decline in economic activity due to the coronavirus pandemic. It is proved that the inefficiency of state economic and social policy has led to an increase in the number of poor people, as well as rising unemployment in the country. According to the results of the study, it is proposed to adjust government programs to ensure the preservation of the middle class and enable it to realize its potential in stimulating economic growth, human capital development and supporting the development of civil society in Jordan.
\end{abstract}

Keywords: middle class, welfare economics, income distribution, economic development, public policy.

JEL Classification: I3.

Cite as: Aljaloudi, J. (2021). The Decline Of The Middle Class In Jordan. SocioEconomic Challenges, 5(1), 2834. https://doi.org/10.21272/sec.5(1).28-34.2021.

Received: 24.11 .2020

Accepted: 26.01.2021

Published: 30.03 .2021

Copyright: (C) 2021 by the author. Licensee Sumy State University, Ukraine. This article is an open access article distributed under the terms and conditions of the Creative Commons Attribution (CC BY) license (https:// creativecommons.org/licenses/by/4.0/).

\section{Introduction}

Attention to the middle class and its importance in Jordanian society was won by governments, politicians, academics and the media. Some of them believe that their size of the middle class was decreased, especially after the Jordanian governments canceled support for many basic commodities for the Jordanian family, the deterioration of economic conditions resulting from low economic growth rates and high unemployment rates. The results of the study conducted by the Jordanian Economic and Social Council in 2010 showed that the size of the middle class in Jordan was 41.1\% (Economic and Social Council, 2008). By comparison with the result of 2008, the size of the middle class in Jordanian society decreased by $10 \%$. (Ministry of Planning and International Cooperation, 2012). But Dang and Lanchoviching (2016) showed that no change in the middle class size ( $51 \%$ ) in Jordan between the mid and end of 2000s. The current government is working to achieve the state of solidarity within its plan for the years 2019-2020, by expanding the scope of social protection and developing the outputs of public education, improving the level of health care and developing the public transportation system. 
(http://www.pm.gov.jo). The government's implementation of these programs and policies has been based on royal directives that stress the necessity of preserving the middle class and its role in the economy .His Majesty, the king, affirmed this also during his meeting with businessmen, he mentioned the importance of supporting the middle class within the economic reform plan, thus alerting the government, deputies, and public opinion to an important economic fact that without the middle class, there would be no vital economy at all.

The aim of this study is to measure the extent of the decline in the size of the middle class in Jordanian society during the period 2010-2017. This will be done through the use of different methods agreed upon by economic researchers in this field worldwide. The estimation of the size of middle class in Jordan was based on the results of the household income - expenditure surveys, which they published by the Jordan Department of Statistics in the year 2010 and 2017.

This study in the first part deals with the definition and importance of the middle class. In the second part, a discussion of the theoretical framework of the concept of the middle class and its role in society, as well as how to measure its size by reviewing the different methods used by researchers in experimental studies. Field studies related to measuring the size of the middle class will be reviewed. The change in the size of the middle class in Jordan during the period 2010-2017 will be measured using the three measurement methods chosen in Part Four. In the last part of it the results will be analyzed and conclusions written.

\section{Definition and importance of the middle class}

\subsection{Definition of middle class}

There is a difference in the concept of the middle class between economic, social and political thinkers (Abu Ismail and Sarangi, 2015). Karl Marx classified classes in society based on ownership of means of production. While Max Weber rated it on the following criteria: wealth, prestige and power (Dur, N. 2011). Social researchers in social science after them differed in their opinions in the definition of the middle class. For example, classes have been defined by role and position (Mosca, 1939), inter-marriage (Schumpeter (1951) authority relations (Dahrendorf(1959), Status rank (Warner(1960) and Lenski (1966), degree of structuration (Giddens (1973)), cross-classification of property and authority (Ossowski (1963); Wright (1979)) and property, employment and authority relations (Goldthorpe (1987), Erikson and Goldthorpe (1992)). Also, economic researchers differed in their definitions of the middle class based on the different methods they used to measure, but their common denominator is the adoption of the household income or household expenditures as indicators in their estimates. For example: The middle class is the share of the total family or (individuals) in society with incomes ranging from 0.75 to 1.25 of the median income (Throw (1987), Birdsall, Graham and Pettinato (2000)). The middle class is made up of families between $20 \%-80 \%$ Of the income groups in the society, e.g., the middle 60 percent of income recipients)" (Estache and Leipziger (2009)and Easterly (2001)). But Milanovic and Yitzaki (2001) defined the people middle class, who their absolute Income of PPP \$12-\$50/day/person. Birdsall (2010) definition is the class, who a absolute Income of PPP \$10/person/day but not in the top 5. Nehru (2010), Yuan, et al. (2011), the class, who absolute Income from PPP \$2 to \$20/person/day. McKinsy (2010) Absolute Economic Annual household income between PPP $\$ 13,500$ to $\$ 113,000$. While Ravallion (2009) defined the middle class based on expenditure as the class who absolute Expenditure of PPP \$2-\$13/person/day 5. Banerjee and Duflo (2007) absolute expenditure of PPP \$2- \$10/person/day. Another definition by Ace and Loprest (2005) based on poverty line, the middle class is the households, who their income double of national Poverty line.

\subsection{Importance of Middle Class}

Intellectual interest in the role of the middle class in society is not a recent phenomenon, for instance Landes (1989) talked about it as it analyzed the importance of the middle class in English society in the 7th and 18th century. The middle class is increasingly considered a precondition of stability in the social structures, a means of mitigating inequalities in a society, and a pathway to growth and development. Recently, there has been an increase in researchers' interest in analyzing the importance of the middle class. Some of them emphasize that the middle class is the backbone of the economic system and democracy in the face of globalization (Birdsall, Graham and Pettinato (2000). Others believe that the growing size of the middle class in society leads to greater economic 
growth, less political instability, rapid transformation to democracy, more education, better health and lower poverty (Easterly (2001). The middle class can play a larger role in the public and services sector (Esteban and Ray,1999). The importance of these roles for the middle class in society confirmed by a number of researchers such as: Moore (1966), Collier (1999) Leventouglu (2003) Acemoglu and Robinson (2003). There is a positive relationship between the size of middle class and economic growth (Bannerjee and Duflo (2008). Also, middle class create employment, increase human capital and saving. It also, increase aggregate Demand and encourage investment, which spurs higher level of production and leads to increasing income for everyone. All these aforementioned factors make the middle class vital for any economy (Nirvikar (2005) and Basu (2003).

\section{The Field Studies}

It is noticeable that previous studies adopted different methods to calculate the size of the middle class in society. Some of them is relative and others are absolute. For example, Ravallion (2009) proposed expenditure thresholds per capita for measuring the developing world's middle class. He argued that the relevant threshold should range between households with per capita consumption at or above US\$2 a day per person (which is the median poverty line for 70 developing countries) and households at or below US $\$ 13$ a day per person (the poverty line in the United States of America). That measure implicitly advocates the notion that the middle class comprises those consuming slightly more than the World Bank's preferred poverty line of US\$1.25 per day for the developing world which Chen and Ravallion (2008) proposed. Keeping in mind that the mean consumption varies widely across countries and developing regions, and that the US\$2 to US $\$ 13$ range does not hold well for all developing regions.Other authors have proposed alternative region-specific thresholds for defining the middle class. For example, the Asian Development Bank (Chun 2010) used a range of between US\$2 and US\$20 per day per capita (also in 2005 PPP\$ [purchasing power parity US\$]) to define the middle class in Asia (see Asian Development Bank 2010). Likewise, the African Development Bank (2011) divides the middle class in Africa into two subgroups: a lower middle class whose income or expenditure lies between US\$2 and US\$10 per day per capita and an upper middle class whose income or expenditure lies between US\$10 and US\$20 per day. Similarly, Banerjee and Duflo (2008) proposed two thresholds: between US $\$ 2$ and US\$4 and between US\$6 and US\$10 (per capita per day in 2005 PPP . In line with the higher level of income ( Ferreira et al. (2013), in their study on Latin American and the Caribbean, applied a much higher range of between US\$10 and US\$50 per day per capita. To measure the global middle class, Kharas (2013) applied an even higher per capita per day expenditure or income that ranged between US\$10 and US\$100. As noted earlier, that method was adopted by the 2013 Human Development Report to estimate the size of the world's middle-class population (UNDP 2013). This measure implicitly supports the World Bank's method of measuring the middle class ( $\$ 1.25$ per day per person), Chen and Ravallion (2008). Bearing in mind that average consumption varies greatly between countries and developing countries The range between $\$ 2$ and $\$ 13$ does not apply well to all developing regions The Asian Development Bank (2010) used a range between $\$ 2$ and $\$ 20$ per person per day (also in 2005 PPP \$ [PPP]) to determine Middle class in Asia. African Development Bank in 2011, it divides the middle class in Africa into two subgroups: the lower middle class, whose income or spending ranges between $\$ 2$ and $\$ 10$ a day per person, and the upper middle class, which Her income or expenses range from $\$ 10$ to $\$ 20$ per day. and elsewhere. Banerjee and Duflo (2008), they suggested two thresholds: between $\$ 2$ and $\$ 4$ and $\$ 6$ and $\$ 10$ (Per capita per day in 2005 purchasing power parity in dollars). Ferreira et al. (2013), in their study of Latin America and the Caribbean, they applied a lot a higher range is between $\$ 10$ and $\$ 50$ per person, per day. To measure the global middle class, Kharas (2013) applied a higher per capita spending or income per day range between (\$10 and \$100) . This method was adopted by the United Nations Development Program in 2013 to estimate the size of the middle class population in the world.

Abu-Ismail and Sarang in 2015 conducted a study to measure the change on the middle class size during 19952011. They applied threshold method by measurement the size of middle class, and defined it as following (The expenditure bracket for the middle class ranges between PPP\$3 and PPP\$6.1).

Durr-e-Nayab 2011 calculated the size of the middle class in Pakistan, he used methods adopted by international academic researchers. He pointed out that these methods used to measure the middle class are of an economic 
nature. He classified these methods into two groups (absolute and relative methods). Depending on the definition applied, he found that the size of the middle class ranges efferently.

In 2015, the PEW Research Center published a report entitled "The Global Middle Class Promising More Reality from 2001 to 2011". In this report, changes in the distribution of world population by income from 2001 to 2011 were examined. The analysis included 111 countries, which accounted for $88 \%$ of the world population and $85 \%$ of global output in 2011. This report divided the population in each country into five groups based on a person's daily consumption or household income. Using both metrics is essential because for some countries, such as India and China, only consumption data is available, and for others, such as Brazil and Argentina, only income data is available. The five income groups are poor people living on $\$ 2$ or less per day, low income (\$2.01-10), middle income (\$10.01 - \$20), higher middle income (\$20.01-50), and high income (Over \$ 50)).

The results of this report indicated an increase in the proportion of the global middle class from $7 \%$ in 2001 to $13 \%$ in 2015 . And, also upper middle class increased from $7 \%$ to $9 \%$ during that period. Dang and Ianchovichina in 2016 studied the dynamics of well-being, especially the changes associated with middle-class status in Middle Eastern countries East and North Africa (Jordan among these countries), before and after the Arab Spring Transitions, using objective and subjective measures of well-being. In the absence of plate data, the analysis uses the latest technology Modular panel techniques using frequent cross sections from Expenditure data from household and self-surveys. The results of this study showed that no change in the middle class size ( $51 \%)$ in Jordan between the mid and end of 2000s. In 2010 the Economic and Social Council of Jordan published its study on the appreciation and characteristics of the middle class in Jordan. The Council used the World Bank method (the two times poverty line method) to measure the size of the middle class in Jordan, which was estimated at $41.1 \%$ of the Jordanian society. The originality of this study stems from the fact that it measures the change in the size of the middle class during the period 2010-2017, which previous studies have not conducted. It also continues to use three standard methods adopted by researchers, World Bank, and the Jordanian Economic Council. The importance of the study is due to the increasing public interest and the interest of Jordanian decision-makers in the changes that took place in the middle class, which are expected to be negative, and also the deterioration of the economic and social situation of this class.

It is expected that the Covid-19 crisis has negatively affected the middle class in Jordanian society, i.e. a decrease in its size and an increase in economic pressures through loss of job opportunities and low incomes. The lack of recent official statistical data makes it difficult to measure the extent of negative change in the size of the middle class. Therefore, the study will be limited to the period of time 2010-2017, due to the availability of official published data on the statistical surveys prepared by the Jordanian Department of Statistics in 2010 and 2017.

\section{Data and Methodology}

To estimate the middle class in Jordan and the change in their size during the period 2010 - 2017, the author used following measuring methods, which were used by economic researcher and world bank. These are as following:

1. The median income: the middle class is the share of the total family in society with incomes ranging from 0.75 to 1.25 of the median income.

2. The share of the middle 60 percent of income recipients: the middle class is made up of families between $20 \%-80 \%$ Of the income groups in the society

3. The double of national poverty line: the middle class is the households, who their incomes between four and double of national Poverty line. Theses estimation based on the Household income and expenditure survey in 2010 and 2017, which were conducted by Jordanian Department of Statistic.

\section{The Result}

Table 1 shows an estimate of the size of the middle class in Jordanian society in 2010 and 2017. It shows a decrease in the size of the middle class in Jordanian society during this period. The value of the decline varies depending on the method adopted in the estimate.The decrease was estimated at (3.4\%) according to the median 
income, $(8.7 \%)$ to the poverty line and $(15.4 \%)$ according to the share of the middle 60 percent of income recipients.

Table 1. The change on middle class size in Jordan during (2010-2017)

\begin{tabular}{|l|c|c|c|c|c|c|c|c|c|}
\hline & \multicolumn{3}{|c|}{ 1. Method } & \multicolumn{3}{c|}{ 2. Method } & \multicolumn{3}{c|}{ 3. Method } \\
\cline { 2 - 10 } & \multicolumn{3}{|c|}{ Median income (75-125) } & \multicolumn{2}{c|}{ Double poverty line of the group 60 } \\
\cline { 2 - 10 } & 2010 & 2017 & - & 2010 & 2017 & - & 2010 & 2017 & - \\
\hline Middle class Size (\%) & 39.9 & 36.4 & -3.4 & 41.1 & 32.4 & -8.7 & 61.9 & 51.5 & -15.4 \\
\hline
\end{tabular}

Sources: Author calculation.

This decrease in the size of the middle class in Jordanian society can be explained as following:

1. Slowing the economic growth rate: The average annual growth rate of the economy fell from 8.65 percent in (2001-2009) to 2.56 percent 2010-2017 (see table 2).

2. Increased unemployment in the Jordanian economy: The average annual unemployment rate increased from $12.7 \%$ in $2001-2009$ to $17.2 \%$ in $2010-2017$ (see table 2 )

3. The continuing increase in poverty rates: The annual poverty rate increased from $14.4 \%$ in 2010 to $19.4 \%$ in 2017(see table 2). The continued rise in poverty and unemployment has led to the departure of a number of Jordanian households from the middle class and their entry into the category of the poor.

4. The failure of previous Jordanian governments to implement their economic and social programs, which are supposed to protect the middle class in society and reduce unemployment and poverty .

5. Governments continue the policy of lifting subsidies on many basic goods such as energy, electricity and water, especially for the middle class. In conjunction with the lifting of subsidies, Jordanian governments have worked to raise taxes and public service fees. The last one was, for example, the amendment to the income tax law.

6. The decline in real household income as a result of the continued rise in prices in that era (highly inflation rate).

Table 2. Economic Indicators for Jordanian Economy

\begin{tabular}{|c|c|c|}
\hline Period & $2001-2009$ & $2010-2017$ \\
\hline Average annual real economic growth (\%) & $6.85 \%$ & $2.56 \%$ \\
\hline Unemployment rate (\%) & $12.7 \%$ & $17.2 \%$ \\
\hline Poverty level (\%) & $14.4 \%$ (year 2010) & $19.4 \%($ year 2017) \\
\hline
\end{tabular}

Sources: 1. Department of statistic:" Jordan figures for the, year 2010 and year 2018”. Amman, Jordan. 2. Department of statistic: "poverty report 2010 and 2017". Amman, Jordan.

\section{Conclusion}

This study used three main methods to measure the extent of change in the size of the middle class in Jordanian society during the period 2010-2017. These methods are commonly used by researchers in the field and the World Bank. The results of the assessment indicate the erosion of the middle class in Jordan during that period.

The continuing deterioration of economic conditions, represented by slowing economic growth rates, increasing unemployment rates in Jordan and increasing poverty rates during the past five years, will negatively affect the middle class (the continued decline in its size).

It is also expected that the pressure on the middle class will increase as the COVID-19 crisis continues.

Due to the important role played by the middle class in improving economic growth, increasing employment and income opportunities in society, achieving political stability and activating democratic systems. The researcher believes that the previous government programs should be reviewed and reform programs to ensure the protection of the middle class and the fight against poverty and unemployment.

Funding: self-funded. 
Author contribution: conceptualization, Jameel Aljaloudi; data curation, Jameel Aljaloudi; formal analysis, Jameel Aljaloudi; funding acquisition, Jameel Aljaloudi; investigation, Jameel Aljaloudi; methodology, Jameel Aljaloudi; project administration, Jameel Aljaloudi; resources, Jameel Aljaloudi; software, Jameel Aljaloudi; $\underline{\text { supervision, Jameel Aljaloudi; validation, Jameel Aljaloudi; visualization, Jameel Aljaloudi; writing - original }}$ draft, Jameel Aljaloudi; writing - review \& editing, Jameel Aljaloudi.

\section{References}

1. Abu Ismail, K. and Sarangi, N. (2015). Rethinking the measurement of the middle class. Evidence from Egypt. WIDER working paper 2015/023. Available at: https://doi.org/10.35188/UNU-WIDER/2015/908-4.

2. Acemoglu, D. and J. Robinson (2003). Political Origins of Dictatorship and Democracy. Massachusetts: MIT. Available at: web.mit.edu/14.773/www/Chapter 41.pdf.

3. Acs, G. and P. Loprest (2005). Who Are Low-Income Working Families? Washington, DC: Urban Institute. Available at: https://www.urban.org/sites/default/files/publication/32896/412000-Work-and-IncomeSecurity-from-to--.PDF.

4. Atkinson, A.B., T. Piketty, and E. Saezet (2011). Top Incomes in the Long Run of History. Journal of Economic Literature, 49(1), 3-71. Available at: atkinson-piketty-saezJEL10.pdf (berkeley.edu).

5. Banerjee, A., and E. Duflo (2008). 'What Is Middle Class About the Middle Classes Around the World?' Journal of Economic Perspectives, 22(2), 3-28. Available at: https://www.jstor.org/stable/27648239?seq=1.

6. Birdsall, N. (2010) The (Indispensable) Middle Class in Developing Countries; or, The Rich and the Rest, Not the Poor and the Rest. Centre for Global Development. (Working Paper 207). Available at: https://www.cgdev.org/sites/default/files/1423994_file_Birdsall_Indispensable_Middle_FINAL.pdf.

7. Birdsall, N., C. Graham, and S. Pettinato (2000). Stuck in the Tunnel: Is Globalization Muddling the Middle Class? Working Paper 14. Washington, DC: Brookings Institution. Available at: https://www.researchgate.net/publication/5059759_Stuck_in_the_Tunnel_Is_Globalization_Muddling_the_ Middle_Class.

8. Basu, I. (2003) India's Growing Urge to Splurge. Asia Times Online. Retrieved December 12, 2010, from the World. Available at: https://core.ac.uk/display/6766967.

9. Chen, S. and Ravallion. M. (2008). The Developing World Is Poorer Than We Thought, But No Less Successful in the Fight against Poverty. Policy Research Working Paper 4703. The World Bank Development Research Group August 2008. Available at: http://documents1.worldbank.org/curated/en/526541468262138892/pdf/WPS4703.pdf.

10. Dahrendorf, R. (1959). Class and Class Conflict in Industrial Society. Stanford: Stanford University Press. Available at: https://www.d.umn.edu/cla/faculty/jhamlin/4111/Class\%20and\%20Class\%20Conflict\%20in\%20Industrial \%20Society_files/DahredorfReading1.html.

11. Dang, H. and Ianchovichina, E. (2016). Welfare Dynamics with Synthetic Panels: The Case of the Arab World in Transition. World Bank Policy Research Working Paper No. 7595. Available at: http://documents1.worldbank.org/curated/en/785401468000267287/pdf/WPS7595.pdf.

12. Department of statistic (2010). Household income and expenditure survey 2010, Amman Jordan. Available at: www.dos.gov.jo.

13. Department of statistic (2018). Household income and expenditure survey 2017, Amman Jordan. Available at: www.dos.gov.jo.

14. .Dur,N. (2011). Estimating the middle class in Pakistan. PIDE Working Paper 2011-77. Available at: https://econpapers.repec.org/paper/pidwpaper/2011_3a77.htm.

15. Easterly, W. (2001). The Middle Class Consensus and Economic Development. Journal of Economic Growth 6, 317-335. Available at: https://link.springer.com/article/10.1023/A:1012786330095.

16. Erikson, R. and J. Goldthorpe (1992). The Constant Flux. Oxford: Clarendon Press. Available at: https://www.scirp.org/reference/ReferencesPapers.aspx?ReferenceID=1309635.

17. Esteban, J. and D. Ray (1999) Conflict and Distribution. Journal of Economic Theory, 87, 379-415. Available at: Conflict and Distribution - ScienceDirect. 
18. Giddens, A. (1973). The Class Structure of Advanced Societies. London: Hutchinson. Available at:25813188.pdf (gbv.de)

19. Goldthorpe, J. (1987). Social Mobility and Class Structure in Modern Britain. Oxford: Clarendon Press. Available at: Social Mobility and Class Structure in Modern Britain - John H. Goldthorpe - Oxford University Press (oup.com).

20. Goldthorpe, J. and A. McKnight (2006). The Economic Basis of Social Class. In S. Morgan, D. B. Available at: eprints.1se.ac.uk/6312/1/The_Economic_Basis_of_Social_Class.pdf.

21. Goldthrope, J. (2010). Analyzing Social Inequality: A Critique of Two Recent Contributions from Economics and Epidemiology. European Sociological Review 26:6, 731-744. DOI: https://doi.org/10.1093/esr/jcp046.

22. Landes, D. (1998). The Wealth and Poverty of Nations. New York: Norton. Available at: The Wealth and Poverty of Nations - Wikipedia.

23. Lenski, G. (1966). Power and Privilege. New York: McGraw-Hill. DOI: https://doi.org/10.2307/2574401.

24. Leventouglu, B. (2003). Social Mobility, Middle Class and Political Transitions. 28 Stony Brook: Department of Political Science, Stony Brook University. DOI: 10.1080/1070289X.2014.939191.

25. Nehru, V. (2010). Is there a Middle Class in Asia? World Bank: Poverty Reduction and Economic Management and Private and Financial Sector Department for the East Asia and Pacific Region. Available at: https://blogs.worldbank.org/team/vikram-nehru.

26. Nirvikar, S(2005). Theidea of south asia and the role of the middle class,MPRA paper 1277 . University library oofMunich, Germany. Available at: SSRN-id716582.pdf.

27. McKinsey, T. (2010). Capturing the World's Emerging Middle Class. New York: McKinsey Quarterly. Available at: Capturing the world's emerging middle class $\mid$ McKinsey.

28. Milanovic, B. and S. Yitzhaki (2002) Decomposing World Income Distribution: Does the World Have a Middle Class? Review of Income and Wealth 48:2, 155-178. DOI: https://doi.org/10.1111/1475-4991.00046.

29. Ministry of Planning and International cooperation (2012). Annual Report 2012. Available at: www.moip.gov.jo.

30. Moore, B. (1966) Social Origins of Dictatorship and Democracy: Lord and Peasant in the Making of the Modern World. Boston: Beacon Press. DOI: https://doi.org/10.1017/S0022050700110861.

31. Mosca, G. (1939) The Ruling Class. New York: McGraw-Hill. Available at: https://www.amazon.com/Ruling-Class-Elementi-Scienza-Politica/dp/B000PS0142.

32. Ossowski, S. (1963). Class Structure in the Social Consciousness. London: Routledge and Kegan Paul. Available at: https://www.routledge.com/Class-Structure-in-the-SocialConsciousness/Ossowski/p/book/9781138970830.

33. Prime Minister's website. In the Footsteps of the Renaissance: The Government's Work Priorities for the Years 2019-2020. Available at: https://jordankmportal.com/resources/jordan-renaissance-plan-2019-2020.

34. Ravallion, M. (2009). Are there lessons for Africa from China's success against poverty? World Development, 37(2), 303-313. DOI: 10.12691/ajrd-6-3-3.

35. Schumpeter, J. (1951). Imperialism and Social Classes. New York: Augustus M. Kelley. Available at: https://cdn.mises.org/Imperialism\%20and\%20Social\%20Classes_2.pdf.

36. The Economic and Social Council (2010). Evaluation middle class in Jordan-income and expenditure tends (2008). Available at: https://books.openedition.org/ifpo/5038.

37. Thurow, L. (1987). A Surge in Inequality. Scientific American, 256, 30-37. Available at: https://www.jstor.org/stable/24979382?seq=1. 